\title{
The Influence Of Academic Freedom And University Autonomy On The Attitude To Work By Academic Staff Of Public Universities In Edo And Delta States Of Nigeria
}

\author{
Osarenren-Osaghae, R. I. ${ }^{1}$ \\ E.O. Omoredie ${ }^{2}$ \\ Omoike .D.O. ${ }^{3}$ \\ Aigboje, C.D. ${ }^{4}$
Department of Educational Foundations
and Management, Faculty of
Education ${ }^{1,2,3,4}$, Ambrose Alli University
Edo State, Nigeria

\begin{abstract}
The study examined the relationship between motivation factors and academic staff attitude to work in the public universities in Edo and Delta States, of Nigeria, for the purpose of determining whether motivation factors such as university autonomy and academic freedom, have influence on the attitude to work by academic staff. To guide this study four (4) research questions were asked out of which three (3) hypotheses were formulated to cover the dependent and independent variables. The study adopted the correlational survey design. The population consisted of all the academic staff in the four public universities in Edo and Delta States, which amounted to 2793. An approximated sample of 700 which represented $25 \%$ of the population were administered copies of the questionnaires but only 685 were retrieved out of which 680 were found usable. The content validity was applied to validate the instrument and the reliability of the instrument was found to be 0.77 . The statistical methods used to analyze the data were the mean (X) for the one research question one and Pearson Product Moment correlation coefficient ( $r$ ) for the three hypotheses, which were tested at 0.05 level of significance, after analysis, some of the findings amongst others were that:
\end{abstract}

(1) Attitude to work of academic staff in Edo and Delta States public universities was negative.

(2) Twin factors were found to have significant relationship with academic staff attitude to work in the Edo and Delta States public universities in Nigeria.

Based on these findings, recommendations were proffered.

\section{Introduction}

Every organization is established to accomplish predetermined goals and objectives, education organizations are not left out. It is often said that education is an instrument of change and as World Bank would put it education is fundamental to the development of knowledge, economy and society in all nations [37]. However the actualization of these laudable goals especially in the higher education of some developing nations like Nigeria are thwarted by various problems ranging from inadequate resources such as human, materials, financial, technology, e.t.c, to corruption to interferences from outside community, and attitude to work by academic staff of these institutions.

One of the fundamental conditions for effective realization of goals in any legal entity is the adequate welfare of staff. A well-managed organization usually sees an average worker as the root source of quality and productivity gains. The astronomical increase of schools in every level of education sector in Nigeria and the limited resources available to tackle these increases leaves stakeholders worried about the quality of output from these institutions. The study however is concerned about the academic staff in these universities. Shulman identified the teacher as a major factor in student learning and upon their number, quality and devotion lies the success of any educational system [29]. In the university, teachers have three basic functions (1) to teach (2) to carry out researches and (3) to render community services. These basic duties are anchored to the actualization of university goals and they can only be realized by adequate provision of needs which Vroom called motivation [34]. In this study, needs are seen from Vroom perspective, therefore regarded as any factor or factors that will make a worker exert force or energy to take action to actualize goals (personal and organizational) [34]. The goals of the university amongst others are 
students learning and production of skilled graduates to help champion the nations development, how can the university reach these targets when the cornerstone (teachers) attitude towards their basic responsibilities are not favourable? An organization is effective to the degree that it can achieve its goals; an effective organization will make sure that there is a spirit of cooperation and sense of commitment and satisfaction within the sphere of its influence. Beckeri, Randal and Riegal defined commitment in three dimensions [6]:

1. a strong desire to remain a member of a particular organization

2. a willingness to exert high levels of efforts on behalf of the organization

3. a defined belief in an acceptability of the values and goals of the organization.

People come into work situation with various expectations, when they arrive at the work place; they meet other people who also have their own expectations. Positive individual and group expectations serve as positive factors for the workers. The essence of this is to ensure a situation where the individual's needs are met while the organization is achieving established goals/objectives. Behaviour is encouraged basically through positive reinforcement by those who occupy management positions taking into cognizance the needs and aspirations of its workers.

Attitudes are put up by workers based on the situation at workplace. Attitudes are determinants of behaviour because they are linked with perception, personality and motivation. They have three components of emotions, cognition and behaviour. Job satisfaction is an attitude that individuals have about their jobs, it results from the perception of their jobs based on factors of the work environment such as working conditions, polices and procedures etc. Negative attitude in most cases, is a by-product of dissatisfaction which could manifest itself in various ways [1]. Indiscipline and generally apathy are some negative attitudes displayed by workers to buttress their stand and to be able to manage these traits, it is important to understand the individuals involved and the society itself.

\section{Statement of the Problem}

In Nigeria, government has made commendable efforts to increase access to university education; for instance, the number of universities that were just 37 in 2005 has increased to 127 as at December 2013. To encourage the development of the universities, management policies and staff conditions of service have been so reviewed in such a way as to make the universities attractive and supportive to all stakeholders, especially the academic staff, one way the government has done this is to grant autonomy to the universities in teaching, research and administration, additionally, the salaries, allowances and other entitled benefits of staff particularly the academic staff have so improved not only to positively impact on job performance but also on attitude to work, it is however regrettable from observation and studies by Adepoju, Okecha Haastrup and Adedokun and Youngberg that several university staff especially academics have negative attitude to the work they are employed to do [1] [11] [20] [38]. Personal interaction with students in Nigerian public universities in Edo and Delta States, revealed that academic staff come to lecture halls to teach, evaluate students' performance and even course advise with unprecedented reluctance, researches are only embarked upon for the purpose of their official promotion and politics have replaced community service. This attitude has adverse effects on graduates produced that will take over the development of the nation.

This worrisome situation brought about this research that has look at two vital factors which are silent but needful to the effective management of the universities and the actualization of set goals. These twin factors are university autonomy and academic freedom and are regarded in this study as motivation factors, because they are vital needs to the university. They are viewed in relationship to the attitude to work put up by academic staff and how they affect university management undoubtedly, there are other factors that are also responsible for the decadence of the public universities in Nigeria but this study was only interested in looking at the two important factors that are core to the very idea of "The University". In carrying out this research, the following research questions were asked:

(1) What is the attitude to work by academic staff in public universities in Edo and Delta States of Nigeria? (2) Do motivation have any relationship to their attitude to work? (3) Is university autonomy significantly related to their attitude to work? (4) Is academic freedom significantly related to their attitude to work?

Hypothese were formulated from the above research questions so as to guide the study successfully, these were:

(1) There is no significant relationship between motivation and attitude to work by academic staff of public universities in Edo and Delta States of Nigeria. (2) There is no significant relationship between university autonomy and attitude to work by academic staff of public universities. (3) There is no significant relationship between academic freedom and attitude to work by academic staff of public universities.

These hypotheses were formulated to find out the implication(s), and the effects that the twin factors have on the attitude to work by academic staff and 
the university management. The scope covered the four public universities in Edo and Delta State of Nigeria namely:- University of Benin (UNIBEN), Ambrose Alli University (AAU) Ekpoma, Delta State University (DELSU) Abraka, Federal University of Petroleum Resources (FUPR) Efurun.

\section{Literature Review}

\subsection{The Concept and Erosion of University Autonomy and Academic Freedom}

University autonomy is defined as giving universities the freedom to govern themselves, appoint key officers, determine the conditions of service of their staff, control their students' admissions and academic curricula, control their finances and generally regulate themselves as independent legal entities without undue interference from outside community which include the government and its agencies [9]. The role of universities in human capital development, research and technological innovation and advancement cannot be over emphasized. All over the world investment in university education is a critical component of national development effort. Nations today depend increasingly on knowledge, ideas and skills which are produced in the universities [22]. Nations invest in university education because society expects it to contribute to national development in three principal ways. First, society expects its university to produce the highly skilled personnel in technology, engineering, management and other professions, secondly, universities have the responsibility of producing their own crop of academic personnel that is, the intellectual resource pool that will, through scientific research generate new knowledge and innovation to solve developmental problems. Thirdly, universities produce teachers, administrators and managers for other levels of human resources development institutions. The history of university education in Nigeria started with the Elliot commission of 1943 which moved the establishment of University College Ibadan (UCI) in 1948. UCI was an affiliate of the University of London, when Nigeria attained independence in 1960, the need to train skilled manpower to take over from colonial expatriates heightened [16]. Universities were later established based on felt needs as advised by the Ashby commission of 1959 [33]. Inspite of the tremendous expansionary growth of the university system in Nigeria, the system lacks adequate academic freedom, facilities and infrastructures to absorb the teeming number of applicants each year [33]. The inadequacy of autonomy and academic freedom in the nation's ivory seems to be an impediment to the full realization of the goals of the university. It also appeared that the whole university system had been politicized because of the erosion of the autonomy in the nation's universities. This has a negative effect on the quality of graduates being produced from the ivory tower [5]. University autonomy is a highly significant substructures that is integral to the idea of a university. Universities have always regarded the idea as indispensable values and have defended it due to its inestimable value, Onyeonoru, posited that for autonomy to be fully practiced, there should be no dictatorship from outside the university as to what its standard should be [23]. University autonomy is essential to the advancement, transmission and application of knowledge. It has often been said that for universities in Nigeria to play a meaningful role and discharge its responsibilities effectively, the system must enjoy high degree of autonomy in addition to the academic freedom of its academic staff. While citing examples of France, Japan, the Netherlands, Chile, Thailand and Vietnam, the world bank demonstrated how financial and spending autonomy served as incentives for quality improvement and efficiency of various higher education systems [5]. The best universities according to recent rankings are very autonomous [35].

Every university has its own laws or edicts which spells out the functions of the various organs in the institution such as the governing council, senate, congregation, committee of Deans, Faculty, Department, Institute and so on, for all these organs to succeed in the accomplishment of the organisational goals, the system needs to be autonomous. The system must have the freedom to run its own affairs without external interference it must have the right to organise its internal affairs, to make decisions and to establish its own academic programmes. University autonomy will create a more flexible and responsive management in the areas of teaching and research. Disputes over university autonomy and academic freedom can be traced back to the 1970s where the university college Ibadan came under military dictatorship. A trade dispute between the governing councils of Nigerian universities and the local branches of the National Association of University Teachers in 1973 on the review of conditions of service [23]. History recorded that the federal Ministry of Education opposed vehemently the improved pay and improved condition of services approved to the aggrieved teachers' association by their local councils. The senate of the University of Ibadan also experienced an erosion of its statutory powers in 1978 when a query was issued on it by the Federal Ministry of Education to explain why so many students failed in the 1977/78 academic session Adesina [23]. The academic Staff Union of Universities (ASUU) that has been at the fore-front of the reforms in the Nigeria universities has also been met with stiff oppositions from the federal government. Many 
times ASUU have been banned and unbanned. Many academics have been dismissed, retired and unjustly jailed for teaching what they were not employed to teach [3]. Forty-nine academic staff of the University of Ilorin were dismissed in 2001 for participating in the nation-wide strike called by the Academic Staff of Nigerian Universities [33]. A vice chancellor of Ambrose Alli University was unilaterally sacked by the governor in 2010 and acting vice chancellor was appointed by same, the bursar and registrar of same university was removed in 2011 by the state house of assembly.

There are many universities in Nigerian today controlled by the Federal Government, and the State Government and some by Private individuals and corporate organisations. However, in spite of the autonomy entrenched in laws setting up these universities, government and its agencies and proprietors have continuously imposed conditions of service and bureaucratic and autocratic rules on how the universities should be managed. The following are some of the areas by which the university autonomy has been eroded. The appointment of the vice-chancellors had hitherto been the sole responsibility of the governing councils of universities [23]. However, the decree No. 23, of 1975 when the Federal Government took over the regional universities, the power to appoint and remove vice-chancellors was vested in the head of state or the Federal Military Government as the case may be. Since that time the appointment of the Vicechancellor has become a political affair and the university visitor (Head of State or Governor of the State) has the final say [19]. As a result of this change vice-chancellor over time became increasingly accountable to the visitor. (1) The introduction of the National Universities Commission (NUC). The senate which consists of the Registrars, all professors, all heads of departments and faculty representatives deals with all academic decisions and their execution [19] [24]. However, with the establishment of NUC in 1962 and its reconstitution in 1974 through Decree No. 1 of role of NUC shifted from mere ensuring orderly development of university education, maintaining standards and ensuring adequate funding, to an agency with the power to dictate what to teach and the number of students to be admitted into the universities. The decree 16 of 1985 and its amendment in 1988 dismantled what was left of university autonomy by expanding the functions of NUC. Section 10 of the decree vested in the commission the "power to lay minimum standards for all universities and other institutions of higher learning in the federation and the accreditation of their degrees and academic awards (Onyeonru 2008).

(2) The introduction of quota system was another erosion, the quota system otherwise known as "federal character" is another way by which the autonomy of the university has been eroded according to [5]. The quota system was entrenched in the 1979 constitution with the aim of rectifying the recruitment imbalances which in the past, made one ethnic group/state to supply the entire personnel into federal parastatals (universities inclusive). It was also to ensure equity and fairness in the admission process, the university is therefore under obligation to admit students not entirely on merit but on the quota system as stipulated by the government. (3) Joint Admission and Matriculation Board (JAMB) and the Admission Process is another erosion Utile believed that this organisation was another effort by the government to thwart university autonomy [33]. JAMB is an examination body that was put in place in Nigeria by the Military government in 1978 with the responsibility of conducting entry examinations into the Nigerian universities, but as the years rolled by corruption crept into it, and in order for the universities to regain their integrity which was almost lost with the introduction of Jamb, the idea of post Jamb was introduced and operational today. The idea was to reexamine the candidates who passed Jamb examinations in order to admit qualified candidates. This process is stressful on the candidates and their parents but it is the only way of ensuring the right candidates were admitted. As laudable and desirable as these agencies are, their functional roles tend to impinge on the statutory functions of Nigerian universities, these and other agencies controlling the universities emphasize quality over funding, instead of ensuring adequate funding that will ensure quality [33]. Can Universities be totally autonomous: in conditions like these, the answer is emphatic No.

Usman study of the consequences of inadequate university autonomy found out that (1) academic staff unrests was significantly related to inadequate university autonomy [32]. (2) inadequate funding, human and material resources and research facilities were also found out to be significantly related to inadequate university autonomy, similarly when Okon sought to know how satisfied the academic staff were with university autonomy and academic freedom, in their universities, his findings were that [21]:

$25 \%$ of his respondents agreed they had autonomy but was inadequate for effective management of the universities, $75 \%$ of his respondents agreed they had no autonomy in their universities.

Ekhator also in his study, sought to know the perception of academic staff regarding university autonomy and its effects on seven job facets which included job satisfaction, attitude to work, welfare of staff, university management, leadership, achievements and advancement and he found out among other findings that attitude to work was related to university autonomy. University autonomy 
and academic freedom was ranked first position by academic staff [7].

Academic freedom has been defined as: "The principle designed to protect the teacher from the hazards that tend to prevent him from meeting his obligations in the pursuit of truth" [18]. This definition, however, appears to be in favour of the scholar. The goals of teaching, research and public service certainly requires an academic setting in which the scholar can express himself freely and without inhibitions. University autonomy and academic freedom are conceptualized as twin factors which are regarded as motivation. The twin factors can not work without each other.

\subsection{The Academic Staff Attitude to Work}

The primary duties of the academic staff can only be carried out effectively in a conducive environment. From observation and interviews of students it was deduced that academic staff are hardly found doing their primary duties but are involved in non-academic duties such as money making ventures, politics, corrupt practices of various magnitude, low attendance to lectures, assigning students to mark examination scripts, compile results and work on fellow students files, some even seek greener pastures both home and abroad they have become very materialistic. Incessant strikes are what the university academic staff is known for these days. The effects of these are so numerous that it has so brought the university system to a state of decay that the respect and honour it use to connote very many years back has virtually vanished into the thin air [20]. First of all, students don't read anymore, the consequence of this is the production of half-backed graduates. Secondly, in the political terrain, the academic staff are easily tongue lashed and sacked at will.

The universities have been politicized to the extent that moneys meant for certain projects are diverted, materials are not available to teach and carry out research instead plagiansm takes centre stage in publications, autonomy of both academic staff and the university has been taken over by the government of the day, students involve in outrageous practices with their lecturers, it may be of interest to know that no Nigerian university was listed among the world's top 500 university infact the best universities in Nigeria ranked $5,834^{\text {th }}$ position [20]. The significance of sound university education and vigorous research with regard to the economy cannot be over emphasized. Academic staff are faced with problems that may explain the reason why the universities are faced with problems, for a start, adequate facilities are not there to teach nor carryout researches, remuneration though increased are not paid promptly and not commesurate to effort put in neither can it be compared to other lucrative professions such as banking, oil, Engineering, medicine etc. Government incessant interferences in the running of the university is absurd. Findings from the genuine researches carried out by these academics are not looked at, neither are they used for national development nor recommendations implemented, this situation has discouraged alot of academics making them to think twice about carrying out genuine researches that will not be upheld,. Agreement reached between academic staff and their employers, (in this case the federal and state governments) are not implemented, agreements reached and signed are effective on paper but when it comes to the implementation of the agreement, the government backslides and start to put up another behaviour as if the matter never had an earlier agreement. These and more have brought disappointments, lack of confidence on employers, frustration and outright rebellion of the academic staff and this has brought untold hardship to the university system, that going on strike is a solution to some critical problems. The needs of academic staff met are integral to the attitude they put up at work as confirmed by Aminiye and Asuquo who found out after investigating the university workers perception of the organizational retirement plan and their attitude to work that workers had very low perception of their universities organizational retirement plan therefore the workers attitude was largely unfavourable perhaps because they were not carried along in the plan [2]. One of the most important areas of the work situation that influence attitude, is "work itself" which is often overlooked by managers when addressing the issue of attitude to work. Hofstede collected data from 67 countries and found that the data grouped into four major dimensions and that countries systematically varied along these dimensions [12] [13]. The four crosscultural dimensions were (1) individualism collectivism (2) uncertainty avoidance versus risk taking (3) power distance or the extent to which power is equally distributed and (4) masculinity/femininity, more recently called achievement orientation, for example the United States was found to be high on individualism, low on power distance and low on uncertainty avoidance, thus high risk taking, Whereas mexico was high on collectivism, high on power distance and high on uncertainty avoidance. The four dimensions have been useful framework for understanding crosscultural differences in employees attitude, as well as recognising the importance of cultural causes of employees' attitudes, more recent analyses have shown that country/culture is a strong a predictor of employees attitude as the type of job perse, Hongping also in a related study of motivating teaching staff in times of change in Chinese universities, found out that motivating teaching staff in times of change will minimize unrest and boost 
positive attitude to work, listed below are other determinants of employees attitude according to human resources practitioners (HRP) work itself, Staw and Ross, individual workers disposition, Arvey, Bouchard, Segal and Abraham, Cultural influences, Erez, House, Triandis, Saari, Saari and Erez, Saari and Schneider work situation influences Fried and Ferris Parisi and Weiner, Weiner, environmental factors, individual and organisational factors [4] [8] [10] [14] [15] [17] [25] [26] [27] [28] [30] [31] [36].

\section{Method of Study}

This study adopted the correlational survey design, with the population of all academic staff in all four public universities across Edo and Delta States of Nigeria which amounted to 2793. A sample of 698.25 (25\%) was randomly selected but was approximated to 698 academic staff used for this study. 698 questionnaires were given out but only 685 were retrieved and 680 were found usable. These were analyzed using the statistical tools of "mean" to answer the question and Pearson Product Moment Correlation coefficient ( $r$ ) to test the hypotheses. To determine the mean; the 4-point rating scale, Strongly Agree (SA), Agree (A), Disagree (D), Strongly Disagree (SD), was multiplied by the total number of Ten items in the attitude questionnaire which was thus: $4 \times 10=40$, therefore, 4 was minimum and 40 was maximum points. The maximum point was equally shared such that $1-20$ was regarded as negative attitude and 21-40 was regarded as positive attitude, after analysis the finding was 19.66 which fell within the range of negative attitude, Table 1 shows this.

\section{Analysis and Interpretation}

Question One: What is the attitude to work by academic staff of public universities in Edo and Delta States of Nigeria?

Table 1. The mean of the attitude to work by academic staff in public universities in Edo and Delta States.

\begin{tabular}{|l|l|l|l|}
\hline Variable & N & X & Decision \\
\hline Academic & 680 & 19.66 & Negative \\
Staff Attitude & & & \\
\hline
\end{tabular}

According to Table 1 above, the academic staff of public universities in Edo and Delta States of Nigeria had a mean of 19.66 which represented a negative attitude to work, therefore academic staff of public universities in Edo and Delta States of Nigeria have negative attitude to work.

Hypothesis One: There is no Significant Relationship between Motivation and Attitude to Work by Academic Staff of Public Universities in Edo and Delta States of Nigeria.

Table 2. Pearson's correlation analysis between motivation and attitude to work by academic staff of public universities

\begin{tabular}{|l|c|l|l|l|l|l|}
\hline Variables & $\mathbf{N}$ & $\begin{array}{c}\text { Calculated } \\
\text { value (r) }\end{array}$ & df & $\begin{array}{l}\text { Critical. } \\
\text { Value }\end{array}$ & $\begin{array}{c}\text { Level } \\
\text { of } \\
\text { sig. }\end{array}$ & Decision \\
\hline Motivation & 680 & 0.248 & 678 & 0.1946 & 0.05 & Significant \\
\cline { 1 - 1 } $\begin{array}{l}\text { Attitude to } \\
\text { work }\end{array}$ & & & & & \\
\hline
\end{tabular}

Significant at $\mathrm{p}<.05$

According to table 2, Pearson Product Moment correlation coefficient (r) of .248 is greater than the critical value of .1946, that is to say that the hypotheses was rejected because the calculated value was greater than the critical or table value as relevant to hypothesis one. Result further showed in a post Hoc analysis that a positive and significant relationship exist between motivation and attitude to work by academic staff of the public universities in Edo and Delta States of Nigeria. Thus hypothesis one was rejected at $\mathrm{p}<.05$ therefore the conclusion was that, there is a significant relationship between motivation and attitude to work by academic staff of public universities in Edo and Delta States of Nigeria.

Hypothesis Two:There is no Significant Relationship between University Autonomy and Attitude to Work by Academic Staff in Public Universities in Edo and Delta States of Nigeria.

Table 3. Pearson correlation analysis between university autonomy and attitude to work by academic staff of public universities in Edo and Delta States of Nigeria.

\begin{tabular}{|l|l|l|l|l|l|l|}
\hline Variables & N & $\begin{array}{c}\text { Calculat } \\
\text { ed value } \\
(\mathbf{r})\end{array}$ & Df & $\begin{array}{l}\text { Critical. } \\
\text { Value }\end{array}$ & $\begin{array}{l}\text { Level } \\
\text { of sig. }\end{array}$ & Decision \\
\hline $\begin{array}{l}\text { University } \\
\text { autonomy }\end{array}$ & 680 & 0.281 & 678 & 0.1946 & 0.05 & $\begin{array}{l}\text { Significa } \\
\text { nt }\end{array}$ \\
\hline $\begin{array}{l}\text { Attitude } \\
\text { to work }\end{array}$ & & & & & & \\
\hline
\end{tabular}

Significant at $\mathrm{p}<.05$

According to Table 3, Pearson correlation coefficient was found to be .281 which is greater 
than the table value of .1946. Result further showed in a post-hoc analysis that a positive and significant relationship exit between attitude to work by academic staff and university autonomy. Thus, hypothesis two was rejected at $\mathrm{p}<.05$, the conclusion therefore was that there is a significant relationship between university autonomy and attitude to work by academic staff of public universities in Edo and Delta States of Nigeria.

Hypothesis Three: There is no Significant Relationship between Academic Freedom and Attitude to Work by Academic Staff in Public Universities in Edo and Delta States of Nigeria

Table 4. Pearson correlation analysis between academic freedom and attitude to work by academic staff of public universities in Edo and Delta States of Nigeria.

\begin{tabular}{|l|l|l|l|l|l|l|}
\hline Variable & $\mathbf{N}$ & $\begin{array}{c}\text { Calculated } \\
\text { value }\end{array}$ & df & $\begin{array}{l}\text { Critical. } \\
\text { Value }\end{array}$ & $\begin{array}{l}\text { Level } \\
\text { of sig. }\end{array}$ & Decision \\
\cline { 1 - 5 } $\begin{array}{l}\text { Academic } \\
\text { freedom }\end{array}$ & 680 & 0.302 & 678 & 0.1946 & 0.05 & $\begin{array}{l}\text { Significa } \\
\text { nt }\end{array}$ \\
\cline { 1 - 2 } $\begin{array}{l}\text { Attitude } \\
\text { to work }\end{array}$ & & & & & & \\
\hline
\end{tabular}

Significant at $\mathrm{p}<.05$

According to Table 4, Pearson correlation coefficient of .302 relevant to hypothesis 3 was found greater than the critical value of .1946 which automatically means that this hypothesis has been rejected. Result further revealed from a post-hoc analysis that a positive and significant relationship exist between attitude to work by academic staff and academic freedom. Thus hypothesis three was rejected at $\mathrm{p}<.05$. It was the conclusion of this study that there was a significant relationship between academic freedom and attitude to work by academic staff in public universities in Edo and Delta States of Nigeria.

\section{Discussion and Conclusion}

From the findings above, it can be deduced that academic staff of the public universities in Edo and Delta States of Nigeria have negative attitude to work, it was also found out that motivation was related to academic staff attitude to work and was further found out by this study that university autonomy and academic freedom was related significantly to academic staff attitude to work. This negative attitude to work put up by academic staff of public universities in Edo and Delta States of Nigeria could be as a result of so many intervening variables such as leadership, inadequate and dilapidated teaching and learning facilities, policy and procedures, school community relationship and so on. This study is however concerned about university autonomy and academic freedom as it relates to academic staff attitude to work. A lot has been said earlier about the these twin factor which are indeed inseparable and an integral part of the success of the university system if it has to achieve its set goals and be managed effectively. The academic staff negative attitude to work could be as a result of the insufficient autonomy granted to both the academic staff and the universities. The interferences of the outside community such as the Federal and State governments, who are the proprietors, the reigning political parties in the nation makes it impossible to do meaningful academic work and run the universities effectively and efficiently. Every year, the university calendar is frequently altered perhaps this is one of the reasons why academic staff put up negative attitude towards their primary assignment of teaching, research and community services. Undoubtedly, university autonomy and academic freedom may not be the only factors that contribute to academic staff negative attitude. Academic staff do not seem to have enough power to run the universities. Negative attitude by academic staff could also be due to non-implementation of agreements reached between them and their employer. Strikes both local and national have been embarked upon severally because of this problem which also relate to government over-control and over regulation of the university.

In teaching, comments from students interviewed proved that academic staff reluctantly go to class and from observation appeal letters from the school authorities requesting that academic staff to go to class, monitoring teams have been set up to monitor classes to make sure academics go about their lawful duties in other words academics are threatened to go to class or face the consequences. In research, academic staff only carry out researches for the purpose of their own official promotion and really not for nation building, this is due to the fact that, the findings of studies carried out over the years which ought to have been used by government for nation building are hidden in the pages of the books in library, theses work etc. In the National Policy on Education the Federal government of Nigeria claims to high regards for education as a veritable tool for nation building and development. The total disregard paid to findings have resulted in academic staff reluctance to carry out researches that will not be upheld. Academic staff are not also found doing their community service rather they engage in politics, hustling for official positions, appointments and other businesses besides academic work. These negative attitude may be borne out of inadequacy of university autonomy and academic freedom, for reiteration these are powers, total freedom, given to the university to run itself and the academic staff to 
do research and publish findings unhindered and unharrassed but the reverse is the cases, government incessant interference will not allow the university environment to be conducive for the academic staff to do their job effectively neither will the university management be allowed to manage the university. The university autonomy bill in Nigeria operates in theory not in practice perhaps this is the reason why the cornerstone of the university have negative attitude to work.

The implications of these findings to educational management are that negative attitude to work by academic staff is a pointer to the fact that workers are unhappy and dissatisfied, and according to this study inadequacy of university autonomy and academic freedom which can also be regarded as work situation influences, was found out to be significantly related to academic staff attitude to work. The academic staff want to be in charge of the universities destiny, they want to be in control of the running of the university, the implication therefore is that the amount of power given them to contribute adequately to the university destiny also determine their attitude to work and achievement of goals. The amount of power also given them to carry out all types of researches (classified and unclassified) and publication of the findings of same without hindrances also determine their attitude towards researching publication, conference attendance etc. secondly, the negative attitude to work by academic staff of universities will continue if the motivation factors are not drastically, vigorously and appropriately addressed to produce positive attitude that will change situations around in the universities and consequently in the nation.

\section{Recommendations}

1. For the sake of the students who are the future of the nation and who are the major reason why they are employed, academic staff should try to have a positive attitude to work. They must realize that government can not and never will be able to shoulder all responsibilities regarding motivating them.

2. Since motivation is significantly related to attitude to work by academic staff, it is then imperative that universities proprietors should motivate academic staff to solicit their positive attitude to work. Government must look into the plight of academic staff and take drastic steps to revamp the public universities.

3. University autonomy should not just be a bill, it should be practiced to its fullest. Outside communities such as the political godfathers and Government of the day should hands off the day to day running of the universities, this may help to boost morale and bring about positive attitude to work by academic staff.

4. Academic freedom is essential to the "calling" of academic staff, therefore government must resist the temptation of trying to clamp it down by allowing academic staff the freedom to carry out academic activities that will enhance teaching and learning in the school.

5. To encourage academic staff in their academic pursuit, findings from researches carried out by them must be sought for and implemented for the sake of national development.

\section{References}

[1] Adepoju, S.U. (2006). Motivation, Job Satisfaction and Attitude to Work of White Collar Workers in Communication Sector, Journal of Education and the Economy, 32:1: 41.

[2] Aminiye, S. J. and Asuquo, P. O. (2010). University workers perception of organizational retirement plans and their attitude to work, Kamla Raj Stud. Home Comm Sci 4 (1) 1-9.

[3] Arikewuyo, M.O., (2004). Democracy and University education in Nigeria: Some constitutional considerations. Higher Education Management and policy. A Journal of the Organization for economic Co-operation and Development, 16, 121-134.

[4] Arvey, R.D., Bouchard, T.J., Segal, N.L., \& Abraham, L. M. (1989). Job satisfaction: Environmental and genetic components. Journal of Applied Psychology, 74:187-192.

[5] Babalola, H.B. Jaiyeoba A. O. and Okediran, A. (2007). University autonomy and financial reforms in Nigeria: Historical background, issues and recommendations from experience. Lagos, Bolabay Publications.

[6] Beckeri, V. I. Randal J. O. and Riegal, S. A. (1995). Work motivation; New York Davenport Press.

[7] Ekhator (2007). Analysis of the relationship between job satisfaction and attitude, journal of theory and pratice in education, 5(1), 78-85.

[8] Erez, M. (1994). Towards a model of cross-cultural industrial and organizational psychology. In $\mathrm{H}$. C. Triandis, M. D. Dunnette, \& L. M. Hough (Eds.). Handbook of industrial and organizational psychology 4:1:59-60. Palo Alto, CA: Consulting psychologists press.

[9] Fehnel, R., (2000). Strategic planning and the Nigeria University system innovation Journal of Educational sociology, 49 (2), 31-37. 
[10] Fried, Y., \& Ferris, G.R. (1987). The validity of the job characteristics model: A review and met analysis. Personnel Psychology, 40 (2), 287-322.

[11] Haastrup, T.T., Ekundayo, T.O. and Adedokun, M.O.(2009) The unresolved issues of university autonomy and Academic freedom in Nigeria universities; Humanity and Social Sciences Journal, 61-67.

[12] Hofstede, G. (1980). Culture's consequences: International differences in work-related values. Newbury Park, CA: Sage.

[13] Hofstede, G. (1985). The interaction between national and organizational value systems. Journal of Management Studies, 22:3:347-357.

[14] Hongping, Z. (2006), Motivating teaching staff in times of change in Chinese University; Canadian social science, 2 (4), 37-35.

[15] House, R.J. (1995). Leadership in the twenty-first century: A speculative inquiry. In A. Howard (Ed.) The changing nature of work. San Francisco: Jossey-Bass.

[16] Ike, V.C., (1976). University development in Africa: The Nigerian experience. Ibadan; University of Ibadan Press.

[17] Jackson, T. (2002). The management of people across cultures: Valuing people differently. Human Resource Management, 41:2:455-461.

[18] Kirk, R. (2005). Academic Freedom: An Essay in Definition, Chicago. University of Chicago Press.

[19] Mgbekem, S.D.A.,(2004). Management of University education in Nigeria Calabar; Baye Communications.

[20] Okecha, (2008). The Nigerian university. An Invory tower with neither Ivory nor tower, Edu-Edy publications.

[21] Okon V. W. (2010). University autonomy in Nigeria: the truth of the matter, journal of educational psychology, 52 (2): 99-105.

[22] Oni, B. (2008) Capacity building effort and brain drain in Nigerian Universities? Retrieved from www.uneca.org/docs/conferance-report-and-otherdocument /brain-drain/word-documents/Oni-doc (28/01/09).

[23] Onyeonoru, 1., (2008). University autonomy and cost recovery policies: union contestation and sustainable university system. Retrieved from portal.unesco.org/education/en/files 36322 928/01/09).

[24] Oyeneye, O.Y., (2006). Current issues as it affects the administration of University education in Nigeria. (Unpublished Doctoral Thesis). University of Ado-Ekiti.

[25] Parisi, A.G., \& Weiner, S.P. (1999). Retention of employees: Country-specific analyses in a multinational organization. Presentation at the Four-teeth Annual Conference of the Society for Industrial and Organizational Psychology; Atlanta, GA.
[26] Sarri L.M. (2000). Employee surveys and attitudes across cultures. In Business as unusual? Are I/O Psychology practices applicable across culture? Paper presented at the Fifteenth Annual Conference of the society for Industrial and Organizational Psychology, New Orleans, LA.

[27] Sarri, L.M., \& Erez, M. (2002). Cross-cultural diversity and employee attitudes. Paper presented at the Seventeenth Annual Conference of the Society for Industrial and Organizational Psychology, Toronto.

[28] Sarri, L.M., \& Schneider, B. (2001). Going global: Surveys and beyond. Professional workshop presented at the Sixteenth Annual Conference of the society for Industrial and Organizational Psychology, San Diego, CA

[29] Shulman, L. (1988). Knowledge and teaching foundations of the new reform. Havard educational review, 51, pp. 1-22.

[30] Staw, B.M., \& Ross, J. (1985). Stability in the midst of change: A dispositional approach to job attitudes. Journal of Applied Psychology, 70:4:69.

[31] Triandis, H.C. (1994). Cross-cultural industrial and organizational psychology. In H.C. Triandis, M.D. Dunnette, \&L.M. Hough (Eds.), Handbook of industrial and organizational psychology. Palo Alto, CA: Consulting Psychologists Press.

[32] Usman A. H. (2008): University autonomy: A necessity for effective university management, journal of educational psychology 35 (1) 84-92.

[33] Utile, T., (2008). University autonomy and the brain drain syndrome in Nigeria. Being a paper presented at the $3^{\text {rd }}$ conference of the ACU's Human resource Management Network $23^{\text {rd }}-25^{\text {th }}$ May. Trinidad and Tobago.

[34] Vroom, V.H. (1964). Work and Motivation. New York. Wiley Press.

[35] Weber, L. (2006). University autonomy, a necessary, but not sufficient condition for excellence. Presented at IAU/IAUP presidents' symposium. Chiang Mai, Thailand 8-9 December. Retrieved from http://IAU.IAU/edu/university autonomy//2006brief.com.

[36] Weiner, S.P. (2000). Worldwide technical recruiting in IBM: Research and action. New Orleans, LA.

[37] World Bank (1979). Education for all retrieved from http:www/education for all/wbs/edu.org.

[38] Youngberg, C.F. (2009). An Experimental Study of Attitude to Work and Turnover in Relation to Job Expectancies and Self-Expectations, Unpublished Doctoral Dissertation, New York University. 102pp. 